\title{
Natural Radioactivity Assessment and Radiological Hazards in Soils from Qarun Lake and Wadi EI Rayan in Faiyum, Egypt
}

\author{
Saher M. Darwish ${ }^{1}$, Samia M. El-Bahi ${ }^{2}$, Amany T. Sroor ${ }^{2}$, Najat F. Arhoma ${ }^{1}$ \\ ${ }^{1}$ Physics Department, Faculty of Science, Cairo University, Giza, Egypt; ${ }^{2}$ Nuclear Physics Laboratory, Ain Shams University, Fac- \\ ulty of Girls, Heliopolis, Cairo, Egypt. \\ Email: samia_elbahi@yahoo.com
}

Received September $21^{\text {st }}, 2013$; revised October $21^{\text {st }}, 2013$; accepted October $28^{\text {th }}, 2013$

Copyright (C) 2013 Saher M. Darwish et al. This is an open access article distributed under the Creative Commons Attribution License, which permits unrestricted use, distribution, and reproduction in any medium, provided the original work is properly cited.

\begin{abstract}
The activity concentrations of naturally occurring ${ }^{238} \mathrm{U},{ }^{232} \mathrm{Th}$ and ${ }^{40} \mathrm{~K}$ in surface soils along Qarun Lake and Wadi El Rayan located in Faiyum, Egypt were determined. The measurements were carried out through gamma-ray spectrometry using a coaxial HPGe detector. The results were compared with those reported in the literature. The radiological hazard radium-equivalent activity index, external and internal indices, radioactivity level index, absorbed dose rate, annual effective dose rate and total absorbed dose rate associated with radioactivity in all samples were evaluated and compared with recommended values. Correlation studies between pairs of radionuclides were performed and discussed.
\end{abstract}

Keywords: Natural Radioactivity; Radiological Hazards; HPGe Detector; Gamma-Ray Spectrometry

\section{Introduction}

Natural environmental radioactivity and the associated external exposure due to gamma radiation depend primarily on the geological and geographical conditions, and appear at different levels in the soils of each region in the world [1-4]. Study of the level of radionuclides distribution in the environment provides essential radiological information [5-8]. The radiological hazard implication of these radionuclides is due to the internal exposure originating from radionuclides in diet and from inhaled radon gas as well as external exposure generated by cosmic ray and gamma-rays emitted by radioactive element. Therefore, the assessment of gamma radiation dose from natural sources is important as natural radiation is the largest contributor to external dose of the world population.

The aim of this study is to assess the environmental natural radioactivity level in surface soils collected from Qarun Lake and Wadi El Rayan region located in Faiyum, Egypt using a coaxial HPGe detector in a low background configuration through gamma-ray spectrometry technique. This area falls within the agricultural, industrial and urban communities and tourist area which makes this study worthy. It also aims to establish a data baseline to the radioactivity study for the area under investigation that has not been investigated before.

\section{Experimental Technique}

\subsection{Site Description}

Twenty four soil samples are collected from Qarun Lake and Wadi El Rayan in El Faiyum, Egypt (Figure 1). El Faiyum located $130 \mathrm{~km}$ southwest of Cairo. Qarun Lake is a closed saline lake, located in the deepest part of El Faiyum depression at the western desert, $70 \mathrm{~km}$ south Cairo-Egypt between longitudes $30^{\circ} 24^{\prime} \& 30^{\circ} 49^{\prime} \mathrm{E}$ and latitudes of $29^{\circ} 24^{\prime} \& 29^{\circ} 33^{\prime} \mathrm{N}$. Lake Qarun is remnant of an ancient prehistoric lake (Lake Moris). It has an area of about $200 \mathrm{~km}^{2}$. Its greatest length from southwest to northeast is $40 \mathrm{~km}$, and its greatest width is about $5 \mathrm{~km}$. It is surrounded by vast desert at the northern shore and cultivated lands at the south. It is used as a reservoir for the drainage water which is loaded with salts, nutrients and pesticides that may accumulate and eventually contaminate the aquatic environment of El Faiyum province [9, 10]. The drainage water leads to great leaching of salts due to the high evaporation particularly in summer. So, the salinity of the lake increased vigorously with time passes. At the present its salinity is somewhat below that 


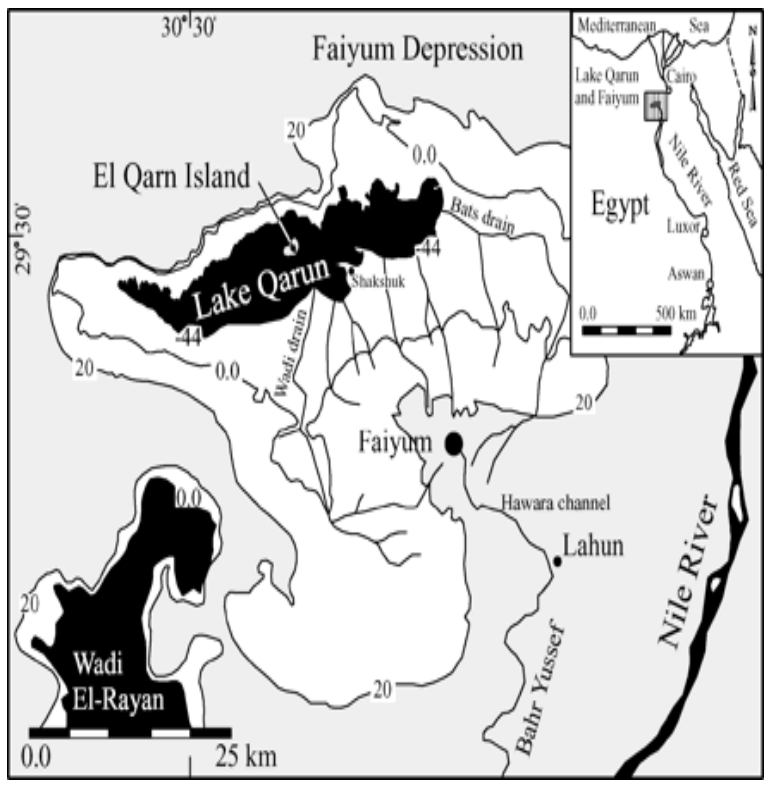

Figure 1. Location map of Qarun Lake and Wadi EI Rayan.

of the Mediterranean Sea; 32.28\% [11].

The valley of Wadi El Rayan stretches on an area of $1759 \mathrm{~km}^{2}$. It lies $65 \mathrm{~km}$ southwest of El Faiyum city and $80 \mathrm{~km}$ west of the River Nile. The reserve is composed of about $50.90 \mathrm{~km}^{2}$ upper lake, $62.00 \mathrm{~km}^{2}$ lower lake and water falls between the two lakes. In addition to springs, of which three are sulphuric springs at the southern side of the lower lake, with extensive mobile sand dunes. Wadi El Rayan waterfalls considered being the largest waterfalls in Egypt. This region suffers from complex problems of pollution as a result of the high salinity in the water and presence of sewage, agricultural drainage flows inside it. Qarun lake water level is currently about $44 \mathrm{~m}$ below mean sea level. Recently, it has risen gradually as a result of an increase in water discharge from agricultural drains and seepage from groundwater aquifers that are probably fed from the Wadi El Rayan Reservoir $[12,13]$.

\subsection{Sampling Preparation}

Twelve surface soil samples from Qarun lake $\left(\mathrm{Q}_{1}\right.$ to $\left.\mathrm{Q}_{12}\right)$ and twelve soil samples from Wadi El Rayan ( $\mathrm{W}_{1}$ to $\mathrm{W}_{12}$ ), were collected from different locations along 12 kilometers, where the distance between each two samples is about one kilometer. The twenty four samples each about $1 \mathrm{~kg}$ in weight, were ground, homogenized and sieved to about 200 mesh size by a crushing machine. The soil samples were air dried and kept in oven for 48 hours at $110^{\circ} \mathrm{C}$. Weighed samples were placed in polyethylene bottles of $250 \mathrm{~cm}^{3}$ volume. The bottles were completely sealed for more than one month to allow radioactive equilibrium to be reached between ${ }^{238} \mathrm{U}$ and ${ }^{232} \mathrm{Th}$ and their corresponding daughters to be measured by gamma spectrometry.

\subsection{Counting System}

The detection system consists of an ORTEC hyper pure germanium (HPGe), preamplifier, spectroscopy, amplifier, high voltage power supply and the pulse height multichannel analyzer. The HPGe detector has a full width at half maximum (FWHM) of $0.9 \mathrm{keV}$ at the $122 \mathrm{keV}$ gamma transition of ${ }^{57} \mathrm{Co}$ and $1.85 \mathrm{keV}$ at $1332.5 \mathrm{keV}$ of ${ }^{60} \mathrm{Co}$ gamma transition. To reduce the gamma-ray background, a cylindrical lead shield with a fixed bottom and a movable cover shielded the detector. The lead shield contained two inner concentric cylinders of copper and cadmium to prevent interference X-rays by lead. The energy calibration of the HPGe spectrometer was carried out by using standard point sources $\left({ }^{60} \mathrm{Co},{ }^{137} \mathrm{Cs},{ }^{226} \mathrm{Ra}\right.$ and ${ }^{241} \mathrm{Am}$ ). Absolute efficiency calibration curves are calculated for activity determination of the sample by using standard ${ }^{232} \mathrm{Th}$ and ${ }^{238} \mathrm{U}$ with activities of 1333.96 and $2120.37 \mathrm{~Bq}$, respectively, contained in the same cylindrical bottles as the samples. The standards and the samples were prepared with a uniform geometry. In order to determine the background distribution in the environment around the detector, an empty bottle was counted in the same manner and geometry as the samples. The background spectra were used to correct the areas of gamma rays for measured isotopes. The quality assurance of the measurements was carried out by a daily efficiency and energy calibration and repeating each sample measurements. The individual samples were either placed on the detector manually during the work and each sample was analyzed for a time of 70000 seconds to obtain the gamma-ray spectrum with good statistics. The gamma emitting radionuclide specifically recorded was ${ }^{238} \mathrm{U},{ }^{232} \mathrm{Th}$ and ${ }^{40} \mathrm{~K}$.

The ${ }^{238} \mathrm{U}$ radionuclide was estimated from the 351.9 $\mathrm{keV}(36.7 \%)$ and $295.2 \mathrm{keV}(13.3 \%)$ gamma peaks of ${ }^{214} \mathrm{~Pb}$ and $609.3 \mathrm{keV}(46.1 \%), 1120.3 \mathrm{keV}(15 \%)$, and $1764 \mathrm{keV}(15.9 \%)$ gamma peaks of ${ }^{214} \mathrm{Bi}$. ${ }^{232} \mathrm{Th}$ radionuclide was estimated from the $338.6 \mathrm{keV}(11.27 \%)$ and $911.1 \mathrm{keV}(29 \%)$ gamma peaks of ${ }^{228} \mathrm{Ac}$ and $583.1 \mathrm{keV}$ $(84.5 \%)$ and $2614.7 \mathrm{keV}(9.9 \%)$ gamma peaks of ${ }^{208} \mathrm{Tl}$ and $238.6 \mathrm{keV}(43.6 \%)$ gamma peak of ${ }^{212} \mathrm{~Pb} .{ }^{40} \mathrm{~K}$ radionuclide was estimated using $1460.8 \mathrm{keV}(10.7 \%)$ gamma peak from ${ }^{40} \mathrm{~K}$ itself was used to determine the concentration of ${ }^{40} \mathrm{~K}$ in different samples.

\section{Results and Discussion}

Analyzing the samples of Qarun Lake and Wadi El Rayan, the activity concentrations for the measured radionuclides of ${ }^{238} \mathrm{U}$ and ${ }^{232} \mathrm{Th}$ are obtained. The activity con- 
centration values of ${ }^{214} \mathrm{~Pb}$ and ${ }^{214} \mathrm{Bi}$ for ${ }^{238} \mathrm{U}$-series, are varied from 6.28 to 16.62 and 15.65 to $33.15 \mathrm{~Bq} / \mathrm{kg}$ for samples of Qarun Lake and varied from 4.59 to 12.43 and 9.12 to $17.09 \mathrm{~Bq} / \mathrm{kg}$ for samples of Wadi El Rayan, respectively. Similarly for ${ }^{232} \mathrm{Th}$-series, the activity concentration values of ${ }^{228} \mathrm{Ac},{ }^{208} \mathrm{Tl}$ and ${ }^{212} \mathrm{~Pb}$ are varied from 13.88 to $41.01,3.42$ to 24.37 and 3.64 to $14.99 \mathrm{~Bq} / \mathrm{kg}$ for samples of Qarun Lake and varied from 10.44 to 23.30, 6.87 to 16.41 and 0.826 to $10.18 \mathrm{~Bq} / \mathrm{kg}$ for samples of Wadi El Rayan, respectively.

\subsection{Activity Concentrations and Ratios}

The activity concentrations of the nuclides reported in each series were used to give the average values of the activity concentrations of ${ }^{238} \mathrm{U}$ and ${ }^{232} \mathrm{Th}$ for all samples of Qarun Lake and Wadi El Rayan listed in Tables 1 and 2 , respectively. Also the measured activity concentration of ${ }^{40} \mathrm{~K}$ are presented for all samples. It is apparent that the activity concentrations for soil samples of Qarun Lake are ranged from 9.87 to $27.28 \mathrm{~Bq} / \mathrm{kg}, 9.35$ to $26.67 \mathrm{~Bq} / \mathrm{kg}$ and 958.32 to $3306.39 \mathrm{~Bq} / \mathrm{kg}$, with mean values 15.92 $\mathrm{Bq} / \mathrm{kg}, 15.22 \mathrm{~Bq} / \mathrm{kg}$ and $1644.66 \mathrm{~Bq} / \mathrm{kg}$ for ${ }^{238} \mathrm{U},{ }^{232} \mathrm{Th}$ and ${ }^{40} \mathrm{~K}$ respectively. The activity concentrations for soil samples of Wadi El Rayan are ranged from 6.8 to 14.56 $\mathrm{Bq} / \mathrm{kg}, 6.64$ to $19.63 \mathrm{~Bq} / \mathrm{kg}$ and 675.66 to $1288.01 \mathrm{~Bq} / \mathrm{kg}$, with mean values $10.21 \mathrm{~Bq} / \mathrm{kg}, 11.05 \mathrm{~Bq} / \mathrm{kg}$ and 927.44 $\mathrm{Bq} / \mathrm{kg}$ for ${ }^{238} \mathrm{U},{ }^{232} \mathrm{Th}$ and ${ }^{40} \mathrm{~K}$ respectively. The mean activity concentrations of ${ }^{238} \mathrm{U},{ }^{232} \mathrm{Th}$ and ${ }^{40} \mathrm{~K}$ are $0.37,0.44$ and 3.22 times of the world wide average concentrations of these radionuclides 35,30 and $400 \mathrm{~Bq} / \mathrm{kg}$, re-

Table 1. Average activity concentrations of ${ }^{238} \mathrm{U},{ }^{232} \mathrm{Th}$ and ${ }^{40} \mathrm{~K}$ (in $\mathrm{Bq} / \mathrm{kg}$ ) as well as the ${ }^{238} \mathrm{U} /{ }^{232} \mathrm{Th}$ and ${ }^{238} \mathrm{U} /{ }^{40} \mathrm{~K}$ ratios in surface soil samples of Qarun Lake.

\begin{tabular}{|c|c|c|c|c|c|}
\hline $\begin{array}{l}\text { Sample } \\
\text { Code }\end{array}$ & $\frac{{ }^{238} \mathrm{U}}{\mathrm{Bq} / \mathrm{kg}}$ & $\frac{232 \mathrm{Th}}{\mathrm{Bq} / \mathrm{kg}}$ & $\frac{40 \mathrm{~K}}{\mathrm{~Bq} / \mathrm{kg}}$ & ${ }^{238} \mathrm{U} /{ }^{232} \mathrm{Th}$ & ${ }^{238} \mathrm{U} /{ }^{40} \mathrm{~K}$ \\
\hline Q1 & 12.50 & 10.79 & 1022.05 & 1.16 & 0.012 \\
\hline $\mathrm{Q}_{2}$ & 13.85 & 11.34 & 1149.62 & 1.22 & 0.012 \\
\hline $\mathrm{Q}_{3}$ & 16.59 & 15.84 & 1684.59 & 1.05 & 0.010 \\
\hline $\mathrm{Q}_{4}$ & 20.53 & 21.56 & 2347.96 & 0.95 & 0.009 \\
\hline $\mathrm{Q}_{5}$ & 16.59 & 11.32 & 1678.04 & 1.47 & 0.010 \\
\hline $\mathrm{Q}_{6}$ & 13.07 & 13.11 & 1246.00 & 1.00 & 0.010 \\
\hline $\mathrm{Q}_{7}$ & $9.87^{*}$ & $9.35^{*}$ & $958.32^{*}$ & 1.06 & 0.010 \\
\hline $\mathrm{Q}_{8}$ & 16.08 & 14.91 & 1666.59 & 1.08 & 0.010 \\
\hline $\mathrm{Q}_{9}$ & 14.37 & 14.77 & 1468.34 & 0.97 & 0.010 \\
\hline $\mathrm{Q}_{10}$ & 12.87 & 13.07 & 1280.14 & 0.98 & 0.010 \\
\hline $\mathrm{Q}_{11}$ & $27.28^{* *}$ & $26.67^{* *}$ & $3306.39^{* *}$ & 1.02 & 0.008 \\
\hline $\mathrm{Q}_{12}$ & 17.49 & 19.89 & 1927.88 & 0.88 & 0.009 \\
\hline Mean value & 15.92 & 15.22 & 1644.66 & 1.05 & 0.010 \\
\hline P.L. & 35 & 30 & 400 & & \\
\hline
\end{tabular}

*The lowest value; ${ }^{* *}$ The highest value.
Table 2. Average activity concentrations of ${ }^{238} \mathrm{U},{ }^{232} \mathrm{Th}$ and ${ }^{40} \mathrm{~K}$ (in $\mathrm{Bq} / \mathrm{kg}$ ) as well as the ${ }^{238} \mathrm{U} /{ }^{232}$ Th and ${ }^{238} \mathrm{U} /{ }^{40} \mathrm{~K}$ ratios in surface soil samples of Wadi El Rayan.

\begin{tabular}{cccccc}
\hline $\begin{array}{c}\text { Sample } \\
\text { Code }\end{array}$ & $\frac{{ }^{238} \mathrm{U}}{\mathrm{Bq} / \mathrm{kg}}$ & $\frac{{ }^{232} \mathrm{Th}}{\mathrm{Bq} / \mathrm{kg}}$ & $\frac{{ }^{40} \mathrm{~K}}{\mathrm{~Bq} / \mathrm{kg}}$ & ${ }^{238} \mathrm{U} /{ }^{232} \mathrm{Th}$ & ${ }^{238} \mathrm{U}{ }^{40} \mathrm{~K}$ \\
\hline $\mathrm{W}_{1}$ & 7.87 & 8.57 & 964.56 & 0.92 & 0.008 \\
$\mathrm{~W}_{2}$ & 10.89 & 12.01 & 1013.09 & 0.91 & 0.011 \\
$\mathrm{~W}_{3}$ & 9.83 & 11.04 & 881.94 & 0.89 & 0.011 \\
$\mathrm{~W}_{4}$ & 7.62 & $6.64^{*}$ & 728.16 & 1.15 & 0.010 \\
$\mathrm{~W}_{5}$ & $6.86^{*}$ & 7.03 & $675.66^{*}$ & 0.98 & 0.010 \\
$\mathrm{~W}_{6}$ & 9.98 & 9.76 & 1244.21 & 1.02 & 0.008 \\
$\mathrm{~W}_{7}$ & 7.19 & 7.51 & 713.01 & 0.96 & 0.010 \\
$\mathrm{~W}_{8}$ & 10.41 & 10.84 & 864.52 & 0.96 & 0.012 \\
$\mathrm{~W}_{9}$ & 10.13 & 9.95 & $1288.01^{* *}$ & 1.02 & 0.008 \\
$\mathrm{~W}_{10}$ & 12.91 & 14.94 & 902.85 & 0.86 & 0.014 \\
$\mathrm{~W}_{11}$ & $14.56^{* *}$ & $19.63^{* * *}$ & 950.38 & 0.74 & 0.015 \\
$\mathrm{~W}_{12}$ & 14.29 & 14.69 & 902.85 & 0.97 & 0.016 \\
Mean value & 10.21 & 11.05 & 927.44 & 0.92 & 0.011 \\
P.L. & 35 & 30 & 400 & & \\
\hline
\end{tabular}

*The lowest value, ${ }^{* *}$ The highest value.

spectively reported by [8]. In regard to the high values of ${ }^{40} \mathrm{~K}$ activity concentrations, at this stage it is not yet clear whether this is a result of geological variation or reflects some influence of the intensive farming activities in the area under study.

The ${ }^{238} \mathrm{U} /{ }^{232} \mathrm{Th}$ and ${ }^{238} \mathrm{U} /{ }^{40} \mathrm{~K}$ concentration ratios were evaluated from the measured values of activity concentrations. The mean values of ${ }^{238} \mathrm{U} /{ }^{232} \mathrm{Th}$ and ${ }^{238} \mathrm{U} /{ }^{40} \mathrm{~K}$ ratios were 1.05 and 0.010 for Qarun lake and 0.92 and 0.011 for Wadi El Rayan soil samples, respectively. These are comparable to the mean values reported for the soils of Greece (1.10 $\pm 44 \%$ and $0.06 \pm 56 \%$, [14]), USA (1.15 and $0.11,[15])$, India (1.42 and 0.26 [16]). and China (0.76 and $0.06,[15])$.

\subsection{Radiological Hazard Indices}

The activity concentrations of ${ }^{238} \mathrm{U},{ }^{232} \mathrm{Th}$ and ${ }^{40} \mathrm{~K}$ measured in each of the studied samples indicate the quantity of radioactivity present but do not provide a measure of radiation hazard. The hazard associated with radioactivity in samples is assessed through hazard indices. A hazard index is a parameter that is represented by a single value that takes into account the measured activity concentrations of ${ }^{238} \mathrm{U},{ }^{232} \mathrm{Th}$ and ${ }^{40} \mathrm{~K}$ in the sample. The various types of radiological hazard indices are the radium equivalent activity, external and internal hazard indices, radioactivity level index, dose rate, annual effective dose and total absorbed dose rate.

The radium equivalent activity index $\left(\mathrm{Ra}_{\mathrm{eq}}\right)$ can be calculated from the following relation [17]: 


$$
R a_{e q}=A_{R a}+1.43 A_{T h}+0.077 A_{K}
$$

where $A_{R a}, A_{T h}$ and $A_{K}$ are the activity concentrations in $\mathrm{Bq} / \mathrm{kg}$ of ${ }^{238} \mathrm{U},{ }^{232} \mathrm{Th}$ and ${ }^{40} \mathrm{~K}$, respectively.

The external $\left(\mathrm{H}_{\mathrm{ex}}\right)$ and internal $\left(\mathrm{H}_{\mathrm{in}}\right)$ hazard indices due to the emitted gamma-rays of the samples are calculated and examined according to the following criterion [17]:

$$
\begin{aligned}
& H_{e x}=A_{R a} / 370+A_{T h} / 259+A_{K} / 4810 \leq 1 \\
& H_{\text {in }}=A_{R a} / 185+A_{T h} / 259+A_{K} / 4810 \leq 1
\end{aligned}
$$

The representative level index $\left(I_{\gamma}\right)$ is defined from the following formula [18]:

$$
I_{\gamma r}=A_{R a} / 150+A_{T h} / 100+A_{K} / 1500 \leq 1
$$

Absorbed dose rate: The absorbed gamma dose rate in air at $1 \mathrm{~m}$ above the ground level using the following equation [8]:

$$
D_{\text {air }}(n G y / h)=0.427 A_{U}+0.662 A_{T h}+0.043 A_{K}
$$

The annual effective dose rate (AED) outdoors in units of $\mu \mathrm{Sv}$ per year is calculated by the following formula [8]:

Annual effective dose rate

$$
=D_{\text {air }}(n G y / h) \times 8760 h \times 0.2 \times 0.7(S v / G y) \times 10^{-3}
$$

In the UNSCEAR (2000), the committee used 0.7 $\mathrm{Sv} / \mathrm{Gy}$ for the conversion coefficient from absorbed dose in air to effective dose received by adults and 0.2 for the outdoor occupancy factor.

The absorbed dose rate in air surrounded by infinite thicknesses of soils can be calculated according to the following formula $\left(\mathrm{D}_{4 \pi}\right)[19,20]$ :

$$
D_{4 \pi}=0.104 A_{R a}+0.130 A_{T h}+0.09 A_{K}
$$

where $\mathrm{D}_{4 \pi}\left(10^{-8} \mathrm{~Gy} / \mathrm{hr}\right)$ refers to the total absorbed dose rate.

Table 3 gives the radium equivalent $\left(\mathrm{Ra}_{\mathrm{eq}}\right)$ in $(\mathrm{Bq} / \mathrm{kg})$, external $\mathrm{H}_{\mathrm{ex}}$ and internal $\mathrm{H}_{\mathrm{in}}$ hazard indices in $(\mathrm{mGy} / \mathrm{y})$, radioactivity level index $\left(\mathrm{I}_{\gamma \mathrm{rr}}\right)$, dose rate in $(\mathrm{nGy} / \mathrm{h})$, annual effective dose rate outdoor in $(\mu \mathrm{Sv} / \mathrm{y})$ and total absorbed dose rate in air surrounded by infinite thicknesses of study area $\mathrm{D}_{4 \pi}\left(10^{-8} \mathrm{~Gy} / \mathrm{h}\right)$ for soil samples from Qarun lake and Wadi El Rayan. The calculated values of of radium equivalent $\mathrm{Ra}_{\mathrm{eq}}$ due to the presence of ${ }^{238} \mathrm{U},{ }^{232} \mathrm{Th}$ and ${ }^{40} \mathrm{~K}$ in soil samples are ranged from 97.03 to 320.01 $\mathrm{Bq} / \mathrm{kg}$ and from 68.94 to $123.54 \mathrm{~Bq} / \mathrm{kg}$ for Qarun lake and Wadi El Rayan samples, respectively which are lower than the recommended limit $370 \mathrm{~Bq} / \mathrm{kg}$ [8]. The calculated values of external hazard and internal hazard indices are ranged from 0.26 to 0.86 and from 0.29 to 0.94 $\mathrm{mGy} / \mathrm{y}$, respectively for Qarun lake and ranged from 0.18 to 0.33 and 0.21 to $0.36 \mathrm{mGy} / \mathrm{y}$, respectively for Wadi El Rayan. Both are lower than unity that keeps the radiation hazard insignificant.

The values of the of radioactivity level index $I_{\gamma r}$ are ranged from 0.79 to 2.65 for Qarun Lake samples, which is higher than the recommended unity value except for the three $\mathrm{Q}_{1}, \mathrm{Q}_{2}$ and $\mathrm{Q}_{7}$ samples which are lower than unity. The values of radioactivity level index $I_{y r}$ are ranged from 0.57 to 1.03 for Wadi El Rayan samples, which are lower than the recommended value unity. The values of absorbed dose rate are ranged from 51.61 to 171.48 $\mathrm{nGy} / \mathrm{h}$ for Qarun lake samples which is higher than the recommended limit (59 $\mathrm{nGy} / \mathrm{h})$ [8], except for values of $\mathrm{Q}_{1}$ and $\mathrm{Q}_{7}$ samples which are lower than the recommended limit. The values of the absorbed dose rate for Wadi El Rayan samples are ranged from 36.64 to $66.29 \mathrm{nGy} / \mathrm{h}$ and most of these values are lower than the recommended limit [8], except for values of the three samples $W_{6}$, $\mathrm{W}_{9}$ and $\mathrm{W}_{11}$ which are higher than the recommended limit.

Table 3 also presents the resulting average annual effective dose range from 63.29 to 210.30 and from 44.93 to $81.31 \mu \mathrm{Sv} / \mathrm{y}$, for Qarun lake and Wadi El Rayan samples, respectively which is lower than the world wide average annual effective dose approximately $500 \mu \mathrm{Sv} / \mathrm{y}$ [8]. In this work also, the lowest absorbed dose rate in air surrounded by infinite thicknesses value of study area was found to be 88.49 and $62.44\left(10^{-8} \mathrm{~Gy} / \mathrm{h}\right)$, while the highest value was found to be 303.88 and $118.27\left(10^{-8}\right.$ $\mathrm{Gy} / \mathrm{h}$ ) for Qarun lake and Wadi El Rayan samples. $\mathrm{D}_{4 \pi}$ $\left(10^{-8} \mathrm{~Gy} / \mathrm{h}\right)$ refers to the total absorbed dose rate.

\subsection{Comparison of Activity Concentrations with Similar Studies}

The activity concentrations of ${ }^{238} \mathrm{U},{ }^{232} \mathrm{Th}$ and ${ }^{40} \mathrm{~K}$ observed in the present study were compared with similar literature values of different soils in other regions in Egypt and other countries in the world abroad [8,14,21-36], and the summary of the results is given in Table 4. We find that Qarun lake and Wadi El Rayan soil samples have a highest value of potassium than other areas in Egypt. According to UNSCEAR report, 2000 [8], the world average value of activity concentrations in Egypt for ${ }^{238} \mathrm{U},{ }^{232} \mathrm{Th}$ and ${ }^{40} \mathrm{~K}$ are $5-64 \mathrm{~Bq} / \mathrm{kg}$ (mean value 17 $\mathrm{Bq} / \mathrm{kg}$ ), 2 - $96 \mathrm{~Bq} / \mathrm{kg}$ (mean value $18 \mathrm{~Bq} / \mathrm{kg}$ ) and $29-$ $6590 \mathrm{~Bq} / \mathrm{kg}$ (mean value $320 \mathrm{~Bq} / \mathrm{kg}$ ), respectively. soil, were within the world average range in Egypt.

As shown in Table 4, the radioactivity in soils vary from one country to another. It is important to point out that these values are not representative values for countries mentioned but for the region from where the samples were collected.

\subsection{Correlation Studies}

In order to find the extent of the existence of these radio- 
Table 3. The values of radium equivalent in $(\mathrm{Bq} / \mathrm{kg})$, external and internal hazard indices in $(\mathrm{mGy} / \mathrm{y})$, dose rate in $(\mathrm{nG} / \mathrm{hr})$, annual effective dose (AED) in $(\mu \mathrm{Sv} / \mathrm{y})$ and total absorbed dose rate in $\left(10^{-8} \mathrm{~Gy} / \mathrm{hr}\right)$ for soil samples from Qarun Lake and Wadi El Rayan.

\begin{tabular}{|c|c|c|c|c|c|c|c|}
\hline Sample Code & $\mathrm{Ra}_{\mathrm{eq}}(\mathrm{Bq} / \mathrm{kg})$ & $\mathrm{H}_{\mathrm{ex}}(\mathrm{mGy} / \mathrm{y})$ & $\mathrm{H}_{\text {in }}(\mathrm{mGy} / \mathrm{y})$ & $I_{\gamma r}$ & Dose rate $(\mathrm{nGy} / \mathrm{h})$ & $\operatorname{AED}(\mu \mathrm{Sv} / \mathrm{y})$ & $\mathrm{D}_{4 \pi}\left(10^{-8} \mathrm{~Gy} / \mathrm{h}\right)$ \\
\hline $\mathrm{Q}_{1}$ & 106.63 & 0.29 & 0.32 & 0.87 & 56.43 & 69.20 & 94.69 \\
\hline $\mathrm{Q}_{2}$ & 118.59 & 0.32 & 0.36 & 0.97 & 62.85 & 77.09 & 106.38 \\
\hline $\mathrm{Q}_{3}$ & 168.95 & 0.46 & 0.50 & 1.39 & 90.01 & 110.39 & 155.39 \\
\hline $\mathrm{Q}_{4}$ & 232.15 & 0.63 & 0.68 & 1.92 & 124.00 & 152.08 & 216.25 \\
\hline $\mathrm{Q}_{5}$ & 161.99 & 0.44 & 0.48 & 1.34 & 86.73 & 106.37 & 154.22 \\
\hline $\mathrm{Q}_{6}$ & 127.76 & 0.35 & 0.38 & 1.05 & 67.84 & 83.19 & 115.20 \\
\hline $\mathrm{Q}_{7}$ & $97.03^{*}$ & $0.26^{*}$ & $0.29^{*}$ & $0.79^{*}$ & $51.61^{*}$ & $63.29^{*}$ & $88.49^{*}$ \\
\hline $\mathrm{Q}_{8}$ & 165.73 & 0.45 & 0.49 & 1.37 & 88.39 & 108.41 & 153.60 \\
\hline $\mathrm{Q}_{9}$ & 148.55 & 0.40 & 0.44 & 1.22 & 79.05 & 96.95 & 135.57 \\
\hline $\mathrm{Q}_{10}$ & 130.13 & 0.35 & 0.39 & 1.07 & 69.19 & 84.86 & 118.25 \\
\hline $\mathrm{Q}_{11}$ & $320.01^{* *}$ & $0.86^{* *}$ & $0.94^{* *}$ & $2.65^{* *}$ & $171.48^{* *}$ & $210.30^{* *}$ & $303.88^{* *}$ \\
\hline $\mathrm{Q}_{12}$ & 194.38 & 0.53 & 0.57 & 1.60 & 103.53 & 126.97 & 177.91 \\
\hline $\mathrm{W}_{1}$ & 94.39 & 0.26 & 0.28 & 0.78 & 50.51 & 61.95 & 88.74 \\
\hline $\mathrm{W}_{2}$ & 106.07 & 0.29 & 0.32 & 0.87 & 56.16 & 68.89 & 93.87 \\
\hline $\mathrm{W}_{3}$ & 93.53 & 0.25 & 0.28 & 0.76 & 49.43 & 60.62 & 81.83 \\
\hline $\mathrm{W}_{4}$ & 73.18 & 0.20 & 0.22 & 0.60 & 38.96 & 47.78 & 67.19 \\
\hline $\mathrm{W}_{5}$ & $68.94^{*}$ & $0.19^{*}$ & $0.21^{*}$ & $0.57^{*}$ & $36.64^{*}$ & $44.93^{*}$ & $62.44^{*}$ \\
\hline $\mathrm{W}_{6}$ & 119.74 & 0.32 & 0.35 & 0.99 & 64.22 & 78.76 & 114.29 \\
\hline $\mathrm{W}_{7}$ & 72.83 & 0.19 & 0.22 & 0.59 & 38.70 & 47.46 & 65.89 \\
\hline $\mathrm{W}_{8}$ & 92.48 & 0.25 & 0.28 & 0.75 & 48.79 & 59.84 & 80.29 \\
\hline $\mathrm{W}_{9}$ & $123.54^{* *}$ & $0.33^{* *}$ & $0.36^{* *}$ & $1.03^{* *}$ & $66.29^{* *}$ & $81.31^{* * *}$ & $118.27^{* *}$ \\
\hline $\mathrm{W}_{10}$ & 103.79 & 0.28 & 0.32 & 0.84 & 54.23 & 66.50 & 84.54 \\
\hline $\mathrm{W}_{11}$ & 115.81 & 0.31 & 0.35 & 0.93 & 60.09 & 73.68 & 89.60 \\
\hline $\mathrm{W}_{12}$ & 104.82 & 0.28 & 0.32 & 0.84 & 54.65 & 67.02 & 84.65 \\
\hline PL & 370 & 1 & 1 & 1 & 59 & 500 & \\
\hline
\end{tabular}

${ }^{*}$ The lowest value; ${ }^{* *}$ The highest value.

Table 4. Comparison of activity concentrations of ${ }^{238} \mathrm{U},{ }^{232} \mathrm{Th}$ and ${ }^{40} \mathrm{~K}$ in $(\mathrm{Bq} / \mathrm{kg})$ for surface soil samples of the present work with different locations in Egypt and the world abroad. Figures in brackets are arithmatic means.

\begin{tabular}{|c|c|c|c|c|}
\hline Location & ${ }^{238} \mathrm{U}(\mathrm{Bq} / \mathrm{kg})$ & ${ }^{232} \mathrm{Th}(\mathrm{Bq} / \mathrm{kg})$ & ${ }^{40} \mathrm{~K}(\mathrm{~Bq} / \mathrm{kg})$ & Reference \\
\hline Qarun Lake, Egypt & $9.87-27.88(15.92)$ & $9.35-26.67(15.22)$ & $958.32-3306.39(1644.66)$ & Present work \\
\hline Wadi El Rayan, Egypt & $6.86-14.56(10.21)$ & $6.64-19.63(11.05)$ & $675.66-1288.01(927.44)$ & Present work \\
\hline Al Arish, Sinai Coast & 83 & 92 & 112 & [21] \\
\hline El-Qatamia, Egypt & $0-156.1$ & $5-37.28$ & $41.53-418$ & {$[22]$} \\
\hline Red Sea Coast, Egypt & $9.7-62.0(25.3)$ & $2.3-221.9(31.4)$ & $97.6-1011.3(427.5)$ & [23] \\
\hline Beach Sand, Egypt & -- & 177 & 815 & [24] \\
\hline Burullus Lake, Egypt & $13.5 \pm 1.4$ & $17.4 \pm 1.7$ & $341 \pm 25$ & {$[25]$} \\
\hline Egypt & $5-64(17)$ & $2-96(18)$ & $29-6590(320)$ & {$[8]$} \\
\hline Turkey & $82.3-167.0(115)$ & $151.9-275.6(192)$ & $1015.5-1484.9(1207)$ & [26] \\
\hline West Coast of India & $8.2-68.4(30.6)$ & $5.9-77.2(38.2)$ & $14.6-344.9(152.2)$ & [27] \\
\hline Kalpakkam, India & $5-71(16)$ & $15-776(119)$ & $200-854(406)$ & [28] \\
\hline China & $40.2-44.2(112)$ & $32.6-88.1(71.5)$ & $440-913(672)$ & [29] \\
\hline Taiwan & 36 & $14.8-44.4$ & $148-814$ & [30] \\
\hline Greece & $1-238(25)$ & $1-193(21)$ & $12-1570(360)$ & [14] \\
\hline Spain & $13-165(46)$ & $7-204(49)$ & $48-1586(650)$ & [31] \\
\hline Japan & $6-98(33)$ & $2-88(28)$ & $15-990(310)$ & [32] \\
\hline Ireland & $100-200(60)$ & $3-60(26)$ & $40-800(350)$ & [33] \\
\hline Bangladesh & 84 & 141 & 1944 & [34] \\
\hline Namibia & $45-48(31)$ & $3-38(32)$ & $42-1100(480)$ & [35] \\
\hline USA & $8-160(40)$ & $4-130(35)$ & $100-700(370)$ & [36] \\
\hline World Average & $8-160(32)$ & $4-130(40)$ & $100-700(420)$ & {$[8]$} \\
\hline
\end{tabular}


active nuclides together at a particular place, correlation studies were performed between the combination of radionuclides $\left({ }^{238} \mathrm{U},{ }^{232} \mathrm{Th}\right),\left({ }^{238} \mathrm{U},{ }^{40} \mathrm{~K}\right)$ and $\left({ }^{232} \mathrm{Th},{ }^{40} \mathrm{~K}\right)$. Figure 2 clearly shows a strong correlation between the activities of $\left({ }^{238} \mathrm{U},{ }^{232} \mathrm{Th}\right),\left({ }^{238} \mathrm{U},{ }^{40} \mathrm{~K}\right)$ and $\left({ }^{232} \mathrm{Th},{ }^{40} \mathrm{~K}\right)$ with $\mathrm{N}=12$ (number of samples in each site) and $\mathrm{R}^{2}=$ 0.86, 0.98 and 0.90, respectively for Qarun lake samples. The strong correlations between the activities indicate that the individual result for any one of the radionuclide concentration in each pair is a good predictor of the concentration of the other. Figure 2 also shows a strong correlation between $\left({ }^{238} \mathrm{U},{ }^{232} \mathrm{Th}\right)$ only with $\mathrm{N}=12$ and $\mathrm{R}^{2}=$ 0.91 which means that the two elements accompanied each other, but there is weak correlation between $\left({ }^{238} \mathrm{U}\right.$, $\left.{ }^{40} \mathrm{~K}\right)$ and $\left({ }^{232} \mathrm{Th},{ }^{40} \mathrm{~K}\right)$ with $\mathrm{N}=12$ and $\mathrm{R}^{2}=0.11$ and 0.05 , respectively for Wadi El Rayan samples. It appears in most figures that the number of points less than twelve because points having the same activity concentration in more than one sample (with little difference) coincidence with each other.

\section{Conclusions}

The level of naturally occurring radioactivity in surface soil samples collected from Qarun Lake and Wadi El Rayan region in Faiyum was evaluated using HPGe gamma-ray spectrometry. The results show that the mean activity concentrations of ${ }^{238} \mathrm{U},{ }^{232} \mathrm{Th}$ in soils of Qarun lake and Wadi El Rayan are comparable to reported world-
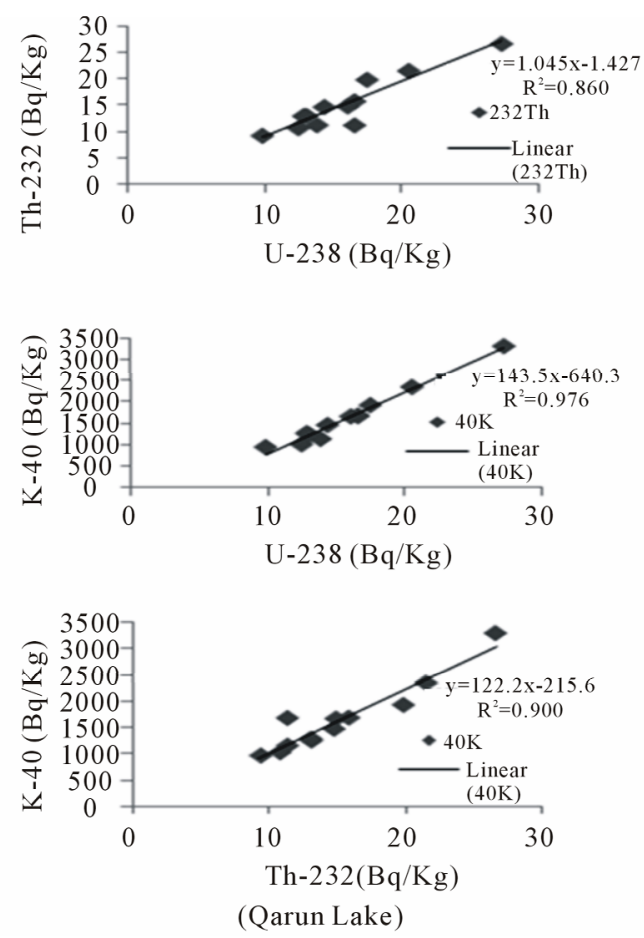

wide range and mean values identified by UNSCEAR (2000). For ${ }^{40} \mathrm{~K}$, the measured activity concentrations are high in both locations compared to the worldwide mean value. It is not yet clear whether this is a result of geological variation or reflects some influence of the intensive farming activities near the area under study. The use of fertilizers in large extent in agricultural soils has affected radionuclides concentration, and especially potassium containing fertilizers are one of the causes of presence of high activity of ${ }^{40} \mathrm{~K}$ in soil.

Also, the results can be useful in the assessment of the radium equivalent $\left(\mathrm{Ra}_{\mathrm{eq}}\right)$, external $\left(\mathrm{H}_{\mathrm{ex}}\right)$ and internal $\left(\mathrm{H}_{\mathrm{in}}\right)$ hazard indices, radioactivity level index $\left(\mathrm{I}_{\gamma \mathrm{r}}\right)$, dose rate (D), annual effective dose rate (AED), outdoor and total absorbed dose rate in the air surrounded by infinite thicknesses of study area $\mathrm{D}_{4 \pi}$ due to naturally radioactive element contents in soil samples from Qarun lake and Wadi El Rayan. Obtained values fall generally below the ranges reported for the worldwide and mean values identified by UNSCEAR (2000) for both locations except for the high values obtained in some of the Qarun Lake soil samples for $I_{\gamma r}, \mathrm{D}, \mathrm{AED}$ and $\mathrm{D}_{4 \pi}$. In regard to the high values, at this location, it is not yet clear whether this is a result of geological variation or reflects some influence of the intensive farming activities in the area under study. The inhabitants around Qarun lake are using the water to irrigate their crops and some of them for washing.
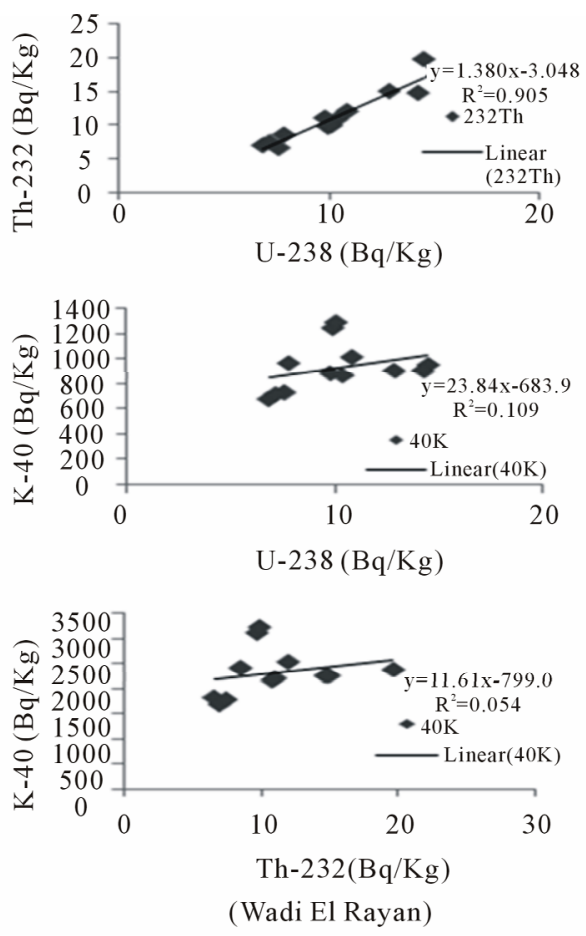

Figure 2. Correlations between concentrations $\left({ }^{238} \mathrm{U},{ }^{232} \mathrm{Th}\right),\left({ }^{238} \mathrm{U},{ }^{40} \mathrm{~K}\right)$ and $\left({ }^{232} \mathrm{Th},{ }^{40} \mathrm{~K}\right)$ for soil samples from Qarun Lake and Wadi El Rayan in Faiyum, Egypt. 
We also noticed that there are strong correlations between $\left({ }^{238} \mathrm{U},{ }^{232} \mathrm{Th}\right),\left({ }^{238} \mathrm{U},{ }^{40} \mathrm{~K}\right)$ and $\left({ }^{232} \mathrm{Th},{ }^{40} \mathrm{~K}\right)$ in soil samples from Qarun Lake, which means that the two elements accompanied each other. Samples of Wadi El Rayan showed strong correlation between $\left({ }^{238} \mathrm{U},{ }^{232} \mathrm{Th}\right)$, which means that the two elements accompanied each other, while there is weak correlation between $\left({ }^{232} \mathrm{Th},{ }^{40} \mathrm{~K}\right)$ and $\left({ }^{238} \mathrm{U},{ }^{40} \mathrm{~K}\right)$. These results would be useful for establishing a data baseline on the gamma background radiation levels in Qarun Lake and Wadi El Rayan in Faiyum and represent a basis to assess any further changes in the radioactivity background levels due to various geological processes or any artificial influences around the area under considerations.

\section{REFERENCES}

[1] S. N. A. Tahir, K. Jamil, J. H. Zaidi, M. Arif and N. Ahmed, "Activity Concentration of ${ }^{137} \mathrm{Cs}$ in Soil Samples from Punjab Province (Pakistan) and Estimation of Gamma Ray Dose Rate for External Exposure," Radiation Protection Dosimetry, Vol. 118, No. 3, 2006, pp. 345-351. http://dx.doi.org/10.1093/rpd/nci351

[2] S. Moura, R. Hernane and Louremjo de Moura, "Melting and Purification of Niobium," AIP Conference Proceedings (American Institute of Physics) [927 (Single CrystalLarge Grain Niobium Technology)], 2007, pp. 165-178.

[3] I. Fatima, J. H. Zaidi M. Arif, M. Daud, S. A. Ahmad and S. N. A. Tahir, "Measurement of Natural Radioactivity and Dose Rate Assessment of Terrestrial Gamma Radiation in the Soil of Southern Punjab, Pakistan," Radiation Protection Dosimetry, Vol. 128, No. 2, 2008, pp. 206-212. http://dx.doi.org/10.1093/rpd/ncm310

[4] V. Partha, N. N. Murthya and P. Raj Saxena, "Assessment of Heavy Metal Contamination in Soil Around Hazardous Waste Disposal Sites in Hyderabad City (India)," Environmental Research and Management, Vol. 2, No. 2, 2011, pp. 27-34.

[5] A. S. Alaamer, "Assessment of Human Exposures to Natural Sources of Radiation in Soil of Riyadh, Saudi Arabia," Turkish Journal Engineering and Environmental Science, Vol. 32, No. 4, 2008, pp. 229-234.

[6] N. N. Jibiri and G. O. Adewuyi, "Radionuclide Contents and Physico-Chemical Characterization of Solid Waste and Effluent Samples of Some Selected Industries in the City of Lagos, Nigeria," Radioprotection, Vol. 43, No. 2, 2008, pp. 203-212. http://dx.doi.org/10.1051/radiopro:2007053

[7] B. Palumbo, M. Angelone and A. Bellanca, "Influence of Inheritance and Pedogenesis on Heavy Metal Distribution in Soils of Sicily, Italy," Geoderma, Vol. 95, No. 3, 2000, pp. 247-266.

http://dx.doi.org/10.1016/S0016-7061(99)00090-7

[8] UNSCEAR, "Sources, Effects and Risk of Ionizing Radiation," United Nations, New York, 2000.

[9] A. A. A. Mageed, "Effect of Some Environmental Fac- tors on the Biodiversity of Holozooplankton Community in Lake Qarun, Egypt," Egyptian Journal of Aquatic Research, Vol. 31, No. 2, 2005, pp. 230-234.

[10] P. J. Mehringer, K. L. Petersen and F. A. Hassan, “A Pollen Record from Birket Qarun and the Recent History of the Fayum, Egypt," Quaternary Research, Vol. 11, No. 2, 1979, pp. 238-256. http://dx.doi.org/10.1016/0033-5894(79)90006-1

[11] Anon, "Studies on the Ecosystem of Lake Qarun and the Surrounding Fish Farms (In Arabic) Freshwater and Manmade Lakes Branch," National Institute of Oceanography and Fisheries, Cairo ARE, 2004.

[12] E. El Sayed and K. A. Guindy, "Hydrochmical Investigation of El Faiyum Locality with Special Reference to the Sulphate Enrichment Phenominon in Lake Qarun," Mansoura Science Bulletin, Vol. 26, No. 1, 1999, pp. 1-21.

[13] H. Ramadan, L. Abu-Zied, W. Kevin, J. K. Roger and Flower, "Environmental Controls on Foraminifera in Lake Qarun, Egypt," Foraminiferal Research, Vol. 37, No. 1, 2007, pp. 136-149.

[14] M. J. Anagnstakis, E. P. Hinis, S. E. Simopoulos and M. G. Angelopoulos, "Natural Radioactivity Mapping of Greek Surface Soil. In: P. K. Hopke, Ed.," The Natural Radiation Environment IV. Environmental International, Vol. 22, No. 1, 1996, pp. 3-8.

[15] UNSCEAR, "Exposure from Natural Sources of Radiation," Report to the General Assembly, with Scientific Annexes, United Nations, New York, 1993.

[16] N. Karunakara, H. M. Somashekarappa, D. N. Avadhani, H. M. Mahesh, Y. Narayana and K. Siddappa, ${ }^{6226} \mathrm{Ra},{ }^{232} \mathrm{Th}$ and ${ }^{40} \mathrm{~K}$ Concentrations in Soil Samples of Kaiga of South West Coast of India," Health Physics, Vol. 80, No. 5, 2001, pp. 470-476. http://dx.doi.org/10.1097/00004032-200105000-00007

[17] J. Beretaka and P. J. Mathew, "Natural Radioactivity of Australian Building Materials, Industrial Wastes and ByProducts," Health Physics, Vol. 48, No. 1, 1985, pp. 8795.

http://dx.doi.org/10.1097/00004032-198501000-00007

[18] N. K. Ahmed and A. M. El-Arabi, "Natural Radioactivity in Farm Soil and Phosphate Fertilizer and Its Environmental Implications in Qena Governorate, Upper Egypt," Journal Environmental Radioactivity, Vol. 84, No. 1, 2005, pp. 51-64. http://dx.doi.org/10.1016/j.jenvrad.2005.04.007

[19] P. Ziqiang, Y. Yin and G. Mingqiang, "Natural Radiation and Radioactivity in China," Radiation Protection Dosimetry, Vol. 24, No. 1-4, 1988, pp. 29-38.

[20] V. Beir, "Health Effects of Exposure to Low Levels of Ionizing Radiation," National Academy Press, Washington DC, 1990.

[21] M. Ibrahim, Gaafar, A. Abu Halawa, A. Sroor and M. Elbarbary, "Environmental Assessment of Natural Radioactivity in El Arish El Bardawil Beach Sands, Mediterranean Coast of Sinai, Egypt," Journal of Environmental Science, Vol. 40, No. 3, 2011, pp. 277-296.

[22] A. Nada, T. M. Abdel-Maksoud, H. M. Abu-Zeid, T. El- 
Nagar and S. Awad, "Distribution of Radionuclides in Soil Samples From a Petrified Wood Forest in El-Qattamia, Cairo, Egypt," Applied Radiation and Isotopes, Vol. 67, No. 4, 2009, pp. 643-649. http://dx.doi.org/10.1016/j.apradiso.2008.11.016

[23] M. H. El Mamoney and A. E. M. Khater, "Environmental Characterization and Radio-Ecological Impacts of NonNuclear Industries on the Red Sea Coast," Journal of Environmental Radioactivity, Vol. 73, No. 2, 2004, pp. 151168. http://dx.doi.org/10.1016/j.jenvrad.2003.08.008

[24] M. A. M. Uosif, A. Taher and A. G. E. Abbady, "Radiological Significance Beach Sand Used for Climatotherapy from Safaga, Egypt," Radiation Protection Dosimetry, Vol. 131, No. 3, 2008, pp. 331-339. http://dx.doi.org/10.1093/rpd/ncn175

[25] H. I. El-Reefy, T. Sharshar, R. Zaghloul and H. M. Badran, "Distribution of Gamma-ray Emitting Radionuclides in the Environment of Burullus Lake," I. Soils and Vegetations Journal of Environmental Radioactivity, Vol. 87, No. 2, 2006, pp. 148-169.

[26] B. Merdanoglu and N. Altinsoy, "Radioactivity Concentrations and Dose assessment for Soil Samples from Kestanbol Granite Area, Turkey," Radiation Protection Dosimetry, Vol. 121, No. 4, 2006, pp. 399-405. http://dx.doi.org/10.1093/rpd/nc1055

[27] N. Karunakara, H. M. Somashekarappa and K. Siddappa, "Natural Radioactivity in South West Coast of India," International Congress Series, Vol. 1276, 2005, pp. 346347. http://dx.doi.org/10.1016/j.ics.2004.11.088

[28] V. Kannana, M. P. Rajana, M. A. R. and R. Ramesh, "Distribution of Natural and Anthropogenic Radionuclides in Soil and Beach Sand Samples of Kalpakkam (India) Using Hyper Pure Germanium (HPGe) Gamma Ray Spetrometry," Applied Radiation and Isotopes, Vol. 57, No. 1, 2002, pp. 109-119. http://dx.doi.org/10.1016/S0969-8043(01)00262-7
[29] Y.-X. Yang et al., "Radioactivity Concentrations in Soils of Xiazhung Granite Area, China," Journal of Applied Radiation and Isotopes, Vol. 63, No. 2, 2005, pp. 255-259. http://dx.doi.org/10.1016/j.apradiso.2005.02.011

[30] P.-S. Weng, "Distribution of Naturally Occurring Radionuclides in the Mountainous Areas in Taiwan," In: K. PhilipHopke, Ed., The Natural Radiation Environment IV. Environment International, Vol. 22, No. 1, 1996, pp. 4954. http://dx.doi.org/10.1016/S0160-4120(96)00088-8

[31] A. Baeza, M. Del Rio, C. Miro and M. Paniagua, "Natural Radionuclide Distribution in Soils of Caceres (Spain)," Journal Environmental Radioactivity, Vol. 23, No. 1, 1994, pp. 19-37. http://dx.doi.org/10.1016/0265-931X(94)90503-7

[32] K. Megumi, T. Okar, M. Doi, S. Kimua, T. Tsujimoto, T. Ishiyama and K. Katsurayama, "Relationships between the Concentrations of Natural Radionuclides and the Mineral Composition of the Surface Soil," Radiation Protection Dosimetry, Vol. 24, No. 1-4, 1988, pp. 69-72.

[33] I. R. McAualy and D. Moran, "Natural Radioactivity in Soil in the Republic of Ireland," Radiation Protection Dosimetry, Vol. 24, No. 1-4, 1988, pp. 47-49.

[34] B. N. Hamid, M. I. Chowdhury, M. N. Alam and M. N. Islam, "Study of Natural Radionuclides Concentration in Area of Elevated Radiation Background in the Northern Districts of Bangladesh," Radiation Protection Dosimetry, Vol. 98, No. 2, 2002, pp. 227-230. http://dx.doi.org/10.1093/oxfordjournals.rpd.a006714

[35] F. Steinhausler and H. Lettner, "Radiometric Survey in the Natural Radiation Environment IV," Radiation Protection Dosimetry, Vol. 45, No. 1\&2, 1992, pp. 553-555.

[36] T. E. Myrick, B. A. Berven and F. F. Haywood, "Determination of Concentrations of Selected Radionuclides in Surface Soil in the United States," Health Physics, Vol. 45, 1983, pp. 631-642. 